\title{
BOREHAN JERUK NIPIS DAN KAPUR SIRIH UNTUK MENURUNKAN LINGKAR PERUT MASA NIFAS
}

\author{
Rusmini, Ayuningtiyas, Esti Handayani \\ Poltekkes Kemenkes Semarang \\ Email: rusminiruswi@gmail.com
}

Riwayat Artikel: Diterima: 1 November 2021, direvisi: 22 November 2021, dipublikasi: 29 November 2021

\begin{abstract}
The tradition of borehan lime and whiting on the abdomen is carried out to speed up the process of decreasing the circumference of the abdomen after childbirth. This research is entitled "The Effect of Lime and Betel Lime Borehan on Decreased Postpartum Abdominal Circumference". The purpose of this study was to determine the effect of postpartum care with lime borehan and betel lime on the decrease in abdominal circumference after delivery. This type of research is quantitative research, the research design used in this study is a quasi-experimental design with pre-test and post-test approaches. The number of samples was 16 people as the control group and 16 people as the treatment group so that the total sample was 32 samples. The results showed that there is an effect of giving borehan lime and whiting to the size of the abdominal circumference of the postpartum mother according to the puskesmas protocol with a t-count value of 2.255 and $p$ 0.032. The lower abdominal circumference of postpartum mothers was found in respondents who were given the lime borehan intervention compared to the abdominal circumference of respondents who only received daily postpartum care.
\end{abstract}

Keywords: Lime Borehan; Betel Lime; Decreased Abdominal Circumference; Postpartum

\begin{abstract}
ABSTRAK
Tradisi borehan jeruk nipis dan kapur sirih pada abdomen dilakukan untuk mempercepat proses penurunan lingkar perut pasca persalinan. Penelitian ini berjudul "Pengaruh Borehan Jeruk Nipis dan Kapur Sirih Terhadap Penurunan Lingkar Perut Masa Nifas". Tujuan dari penelitian ini adalah untuk mengetahui pengaruh perawatan nifas dengan borehan jeruk nipis dan kapur sirih terhadap penurunan lingkar perut setelah melahirkan. Jenis penelitian ini adalah penelitian kuantitatif, desain penelitian yang digunakan dalam penelitian ini adalah quasi-experimental design dengan pendekatan pre-test dan post-test. Jumlah sampel adalah 16 orang sebagai kelompok kontrol dan 16 orang sebagai kelompok perlakuan sehingga jumlah sampel sebanyak 32 sampel. Hasil penelitian menunjukkan bahwa Ada pengaruh pemberian borehan jeruk nipis dan kapur sirih terhadap ukuran lingkar perut ibu nifas sesuai protokol puskesmas dengan nilai t-hitung 2,255 dan p 0,032. Lingkar perut ibu nifas lebih kecil ditemukan pada responden yang diberikan intervensi borehan jeruk nipis dibandingkan dengan lingkar perut responden yang hanya mendapatkan perawatan nifas sehari hari.
\end{abstract}

Kata Kunci: Borehan jeruk nipis; Kapur sirih; Lingkar Perut; Pascapersalinan

\section{Pendahuluan}

Sistem penyembuhan di Indonesia mengalami pluralism. Dimana berbagai cara pengobatan yang berbeda-beda hadir berdampingan termasuk humoral medicine dan elemen magis. Salah satu suku yang ada di Indonesia adalah Jawa, yang merupakan suku terbanyak Masyarakat suku jawa mempunyai cara-cara tertentu dalam 
penyembuhan dan mempunyai persepsi tertentu tentang sehat sakit terkait budaya yang dianut (Pratiwi \& Arifah, 2011).

Setiap daerah memiliki warisan budaya tersendiri dalam merawat ibu pada masa kehamilan dan nifas, kebiasaan tersebut dipraktekan secara turun temurun dari generasi ke generasi. Perawatan post partum merupakan kegiatan sangat diperlukan dalam periode post partum. Perawatan yang dilakukan dengan benar akan mempercepat proses pemulihan kesehatan ibu post partum yang dapat dilihat dari keadaan fisik.

Perawatan masa postpartum mencakup berbagai aspek mulai dari pengaturan dalam mobilisasi, anjuran untuk kebersihan diri, pengaturan diet, pengaturan miksi dan defekasi, perawatan payudara (mammae) yang ditujukan terutama untuk kelancaran pemberian Air Susu Ibu guna pemenuhan nutrisi bayi, dan lain-lain (Mochtar, 2012). Selain perawatan postpartum dengan memanfaatkan system pelayanan biomedical, ada juga ditemukan sejumlah pengetahuan dan perilaku budaya dalam perawatan masa postpartum.

Para ahli antropologi melihat bahwa pembentukan janin, kelahiran dan masa pasca kelahiran umumnya dianggap oleh berbagai masyarakat diberbagai penjuru dunia sebagai peristiwa-peristiwa yang wajar dalam kehidupan manusia. Namun respon masyarakat terhadap berbagai peristiwa juga bisa berbeda seperti di beberapa daerah di jawa tengah yang memiliki pantanganpantangan tertentu dalam aktivitas maupun mengkonsumsi makanan bagi ibu hamil dan bersalin. Seperti masyarakat desa Gading Sari Bantul, sebagai contoh beberapa pantangan dan anjuran pada masa hamil dan nifas yang tidak tertulis, seperti larangan makan buah pisang, anjuran untuk selalu menggunakan peralatan makan yang bersih dan ritual-ritual adat yang dilakukan dalam waktu tertentu (Kasnodihardjo \& Kristiana, 2013). Tumansery menyatakan bahwa perawatan tradisional yang dilakukan oleh ibu postpartum di Kota Sabang meliputi massage, penggunaan ramuan, pantangan makan dan aktivitas serta melakukan kompres di perut dengan menggunakan batu yang dipanaskan maupun ramuan tertentu (Tumansery, 2018).

Masa postpartum adalah masa dimulai beberapa jam sesudah lahirnya plasenta sampai 6 minggu setelah melahirkan. Masa postpartum dimulai setelah kelahiran plasenta dan berakhir ketika alat-alat kandungan kembali seperti keadaan sebelumnya (Marmi, 2014).

Berdasarkan studi pendahuluan yang dilakukan di wilayah Kabupaten Banyumas dari hasil wawancara pada ibu-ibu postpartum banyak yang melakukan tradisi borehan jeruk nipis dan kapur sirih pada abdomen untuk mempercepat proses penurunan lingkar perut pasca persalinan. Banyaknya perasan jeruk nipis yang dipakai adalah satu sendok makan dan ditambah sedikit kapur sirih sebanyak ujung jari, kemudian diborehkan di perut secara melingkar.

Jeruk adalah buah-buahan yang berguna bagi kesehatan dan pencegahan penyakit dan banyak mengandung vitamin $\mathrm{C}$ yang berfungsi untuk daya tahan tubuh. Kandungan senyawa kimia yang terkait efek farmakologis pada jeruk nipis adalah flavonoid, saponin, asam sitrat dan minyak atsiri. Penelitian secara invitro menunjukkan air perasan jeruk nipis pada konsentrasi efektif $8 \%$ memiliki aktivitas antibio film pada bakteri staphylococcus aureus (Khanifah, 2015). Jeruk juga dapat berfungsi sebagai antioksidan, dimana antioksidan tersebut berguna untuk menunda penuaan dini (awet muda) dan juga untuk pelangsingan perut pasca melahirkan. Dalam masa nifas, terjadi kekendoran perut dan strie gravidarum yang timbul pada masa kehamilan, olesan jeruk nipis sangat efektif dalam menghilangkan striae gravidarun dan melangsingkan perut pada ibu nifas dengan pemberian secara benar dan teratur (Puspadewi \& Chasanah, 2014). Ada alternative yang dapat dilakukan dalam melakukan perwatan dengan jeruk nipis untuk penghilang garis pada perut (stria egravidarum), yaitu dengan menambahkan kapur sirih dan minyak kayu putih dan dioleskan secara merata setiap hari sehabis mandi (Yuliarti, 2011).

Penelitian borehan jeruk nipis dan kapur sirih terhadap penurunan lingkar perut belum pernah dilakukan. Sehingga perlu dilakukan penelitian tentang pengaruh perawatan pasca persalinan dalam tradisi Kabupaten Banyumas dengan borehan jeruk nipis dan kapur sirih terhadap penurunan lingkar perut. Penelitian ini dilakukan untuk 
mengetahui pengaruh perawatan postpartum dengan borehan jeruk nipis dan kapur sirih terhadap penurunan lingkar perut pasca persalinan.

\section{Metode Penelitian}

Penelitian ini merupakan penelitian kuantitatif, desain penelitian yang digunakan dalam penelitian ini adalah desain quasi experiment pendekatan pre test dan post test design,yaitu ada dua grup yang digunakan sebagai kelompok perlakuan diukur lingkar perut hari pertama Post Partum sebelum di berikan perlakukan kemudian diukur setelah perlakuan hari ke 8 perlakuan dan 1 grup sebagai kelompok kontrol diukur lingkar perut hari pertama Post Partum berikan perawatan post partum biasa sesuai protap Puskesmas tanpa di berikan borehan dan diukur telah hari ke 8 .

Sampel dalam penelitian ini mempunyai kriteria inklusi pertama lbu nifas yang bersedia menjadi responden di wilayah kerja Puskesmas Sumbang, Kabupaten Banyumas, Jawa Tengah. Kedua ibu nifas dengan kehamilan normal/aterm dan ketiga adalah ibu nifas dengan persalinan Normal pervaginam. Untuk kriteria eksklusinya ibu nifas yang selama waktu penelitian meninggalkan wilayah kerja Puskesmas Sumbang, Kabupaten Banyumas, Jawa Tengah. Jumlah Sampel adalah 16 orang sebagai kelompok Kontrol dan 16 orang sebagai kelompok perlakuan sehingga total sampel adalah 32 sampel.

\section{Hasil dan Pembahasan}

Karakteristik responden pada penelitian ini dapat dilihat pada tabel 1 . Tabel ini memberikan gambaran tentang jumlah responden kelompok kontrol berdasarkan paritas dapat dilihat bahwa jumlah responden sebagian besar kategori P2 yaitu sebanyak 9 orang atau 56.3 persen, dan paling sedikit pada kategori P4 yaitu sebanyak 1 orang atau 6.3 persen. Sedangkan jumlah responden yang berusia antara 30 sampai dengan 34 orang adalah 5 orang atau $31,25 \%$ demikian juga yang berusia 35 samapai dengan 39 sedangkan paling sedikit yaitu $12,5 \%$ pada reponden dengan Usia 20 sampai dengan 24 tahun.
Tabel 1. Karakteristik responden kelompok kontrol berdasarkan paritas dan usia

\begin{tabular}{ccc}
\hline Paritas & Jumlah & $\begin{array}{c}\text { Persentase } \\
(\%)\end{array}$ \\
\hline P1 & 3 & 18.8 \\
P2 & 9 & 56.3 \\
P3 & 3 & 18.8 \\
P4 & 1 & 6.3 \\
\hline Rentang & & \\
Umur & & 12,5 \\
\hline $20-24$ & 2 & 25 \\
$25-29$ & 4 & 31,25 \\
$30-34$ & 5 & 31,25 \\
$35-39$ & 5 &
\end{tabular}

Tabel 2. Karakteristik responden kelompok perlakuan berdasarkan paritas dan usia

\begin{tabular}{ccc}
\hline Paritas & Jumlah & $\begin{array}{c}\text { Persentase } \\
(\%)\end{array}$ \\
\hline P1 & 4 & 25 \\
P2 & 9 & 56.3 \\
P3 & 2 & 12.5 \\
P4 & 1 & 6.3 \\
\hline Rentang & & \\
Umur & & \\
\hline $20-24$ & 2 & 12,5 \\
$25-29$ & 7 & 43,75 \\
$30-34$ & 5 & 31,25 \\
$35-39$ & 2 & 12,5 \\
\hline
\end{tabular}

Tabel 3. Distribusi Frekuensi lingkar perut kelompok kontrol setelah intervensi

\begin{tabular}{ccc}
\hline $\begin{array}{c}\text { Ukuran Lingkar } \\
\text { Perut }(\mathrm{cm})\end{array}$ & Jumlah & Persentase (\%) \\
\hline 81.00 & 1 & 6.3 \\
82.00 & 2 & 12.5 \\
83.00 & 1 & 6.3 \\
84.00 & 3 & 18.8 \\
85.00 & 5 & 31.3 \\
86.00 & 4 & 25.0 \\
\hline Total & 16 & 100.0 \\
\hline
\end{tabular}

Berdasarkan tabel 2 tentang jumlah responden kelompok perlakuan berdasarkan paritas dapat dilihat bahwa jumlah responden sebagian besar kategori P2 yaitu sebanyak 9 orang atau 56.3 persen, dan paling sedikit pada kategori P4 yaitu 
sebanyak 1 orang atau 6.3 persen. Sedangkan responden kelompok perlakuan yang terbanyak berusia 25 sampai dengan 29 tahun berjumlah 7 responden atau $43,75 \%$ sedangkan usia paling sedikit adalah pada usia 35 sampai dengan 39 tahun yaitu 2 orang atau $12,5 \%$.

Dari tabel 3 tentang distribusi frekuensi kelompok kontrol dapat dilihat bahwa ukuran lingkar perut paling besar $86 \mathrm{~cm}$ yaitu sebanyak 4 orang atau 25.0 persen, sedangkan ukuran lingkar perut paling kecil adalah $81 \mathrm{~cm}$ yaitu sebanyak 1 orang atau 6.3 persen. Sedangkan tabel 4 tentang distribusi frekuensi kelompok perlakuan menunjukkan bahwa ukuran lingkar perut paling besar $91 \mathrm{~cm}$ yaitu sebanyak 1 orang atau 6.3 persen, sedangkan ukuran lingkar perut paling kecil adalah $79 \mathrm{~cm}$ yaitu sebanyak 1 orang atau 6.3 persen.

Tabel 4 menjelaskan tentang distribusi frekuensi kelompok perlakuan dapat dilihat bahwa ukuran lingkar perut paling besar $91 \mathrm{~cm}$ yaitu sebanyak 1 orang atau 6.3 persen, sedangkan ukuran lingkar perut paling kecil adalah $79 \mathrm{~cm}$ yaitu sebanyak 1 orang atau 6.3 persen.

Tabel 4. Distribusi Frekuensi lingkar perut kelompok perlakuan setelah tindakan

\begin{tabular}{ccc}
\hline $\begin{array}{c}\text { Ukuran Lingkar } \\
\text { Perut }(\mathrm{cm})\end{array}$ & Jumlah & $\begin{array}{c}\text { Persentase } \\
(\%)\end{array}$ \\
\hline 79.00 & 1 & 6.3 \\
80.00 & 4 & 25.0 \\
81.00 & 1 & 6.3 \\
82.00 & 1 & 6.3 \\
83.00 & 1 & 6.3 \\
84.00 & 3 & 18.8 \\
85.00 & 3 & 18.8 \\
86.00 & 1 & 6.3 \\
91.00 & 1 & 6.3 \\
\hline Total & 16 & 100.0 \\
\hline
\end{tabular}

Pada tabel 5 dapat diketahui nilai rata-rata lingkar perut pasca persalinan untuk responden kelompok kontrol (84.94) lebih besar dibandingkan pada lingkar perut pasca persalinan untuk responden kelompok perlakuan (83.06) dengan nilai perbedaan sebesar 1,88. Dengan demikian secara statistic dapat di gambarkan bahwa lingkar perut ibu nifas lebih kecil ditemukan pada responden yang diberikan intervensi borehan jeruk nipis dibandingkan dengan lingkar perut responden yang hanya mendapatkan perawatan nifas sehari hari. Selanjutnya untuk membuktikan apakah perbedaan signifikan atau tidak dilakukan uji Independent Samples $t$ Test.

Tabel 5. Distribusi rata-rata lingkar perut pasca persalinan pada responden kelompok kontrol dan responden kelompok perlakuan

\begin{tabular}{lcccc} 
Kelompok & Mean & $\begin{array}{c}\text { Std. } \\
\text { Deviation }\end{array}$ & $\mathrm{t}$ & $p$-value \\
\hline Kontrol & 84.94 & 1.18 & 2.25 & 0,036 \\
Perlakuan & 83.06 & 3.11 & & \\
\hline
\end{tabular}

Hasil uji statistik diperoleh nilai thitung sebesar 2,255 dan $p=0,036$ lebih kecil dari nilai $\alpha=0,05$. Hasil tersebut dapat diartikan bahwa ada perbedaan yang signifikan secara statistik antara rata-rata perawatan postpartum dengan borehan jeruk nipis dan kapur sirih dengan yang tidak menggunakan borehan jeruk nipis dan kapur sirih terhadap penurunan lingkar perut pasca persalinan. Sehingga hipotesis yang menyatakan perawatan postpartum dalam tradisi Kabupaten Banyumas dengan borehan jeruk nipis dan kapur sirih berpengaruh terhadap penurunan lingkar perut pasca persalinan dapat diterima.

Berdasarkan hasil diatas bahwa borehan jeruk nipis dan kapur sirih efektif untuk mengecilkan lingkar perut karena air jeruk nipis dan kapur sirih yang mengandung kalsium hidroksida, $\mathrm{Ca}(\mathrm{OH}) 2$ dipercayai dapat mengembalikan perut wanita kepada bentuk asal dan juga mengempiskannya, terkait dengan fungsi borehan jeruk nipis dan kapur sirih efektif bahwa borehan jeruk nipis dan kapur sirih memperkuat otot perut, otot dasar panggul, dan memperlancar sirkulasi pembuluh darah, membantu memperlancar kembalinya otot-otot ke kondisi semula. Sudah di ketahui Bersama bahwa pada masa setelah melahirkan kondisi perut kendor dikarenakan peningkatan berat badan, bergesernya pusat akibat pembesaran rahim sehingga perut diregang begitu lama hal ini juga mengakibatkan lingkar perut meningkat baik selama hamil. Hormon estrogen dan progesteron yang meningkat selama kehamilan menyebabkan terjadinya penambahan jumlah sel dan juga 
pengembangan sel jaringan tubuh termasukpada daerah perut, sehingga memungkinkan perut dapat meregang seiring dengan bertambahnya usia kehamilan. Proses involusi yang terjadi pada masa nifas memungkinkan untuk mengembalikan kondisi fisik ibu ke dalam bentuk semula seperti sebelum hamil walaupun dalam proses yang lama dan belum tentu akan kembali seperti semula. Oleh karena itu banyak metode yang digunakan untuk mempercepat pengembalian bentuk tubuh terutama perut ke lingkar perut yang normal yang salah satunya dengan borehan jeruk nipis dan kapur sirih.

Metode penggunaan borehan jeruk nipis dan kapur sirih sudah dipercaya oleh masyarakat dan dilakukan secara turun temurun di wilayah kabupaten Banyumas kususnya di wilayah Sumbang yang terbukti secara empiris banyak masyarakat yang melakukan perawatan dengan metode borehan jeruk nipis dan kpur sirih. Kebiasaan yang sudah dilakukan secara turun temurun tersebut secara tidak langsung akan mempengaruhi ibu pasca persalinan secara psikologis dan akan menjadi sugesti tersendiri menurunkan lingkar perut, dengan demikian ibu pasca persalianan diwilayah Kabupaten Banyumas banyak yang melakukan perawatan dengan borehan jeruk nipis dan kapur sirih .

Peningkatan lingkar perut selain dipengaruhi oleh faktor hormonal selama kehamilan juga di pengaruhi oleh beberapa faktor diantaranya usia dan paritas. Berdasarkan hasil penelitian ini responden kelompok perlakuan menunjukan bahwa responden dengan usia 30 sampai dengan 34 tahun hasil pengukuran lingkar perut berkisar antara 88 samapi $96 \mathrm{~cm}$ dan pada kelompok kontrol menunjukan bahwa responden dengan usia 30 sampai dengan 34 tahun hasil pengukuran lingkar perut berkisar antara $84 \mathrm{sm}$ sampai dengan 88 $\mathrm{cm}$.

Selain usia, peritas juga mempengaruhi lingkar perut pasca persalinan pada hasil penelitian responden kelompok perlakuan menunjukan bahwa responden dengan paritas 2 sampai dengan 4 hasil pengukuran lingkar perut berkisar antara 85 sampai dengan $96 \mathrm{~cm}$ dan pada kelompok kontrol menunjukan bahwa responden dengan Paritas 2 sampai dengan 4 hasil pengukuran lingkar perut berkisar antara 84 sampai dengan 89 $\mathrm{cm}$.

Berdasarkan data karakteristik responden berdasarkan Usia didapatkan data responden usia terbanyak yaitu ada $25 \%$ responden yang berusia 35 th dan $6 \%$ beruia 38 tahun. Menurut hasil penelitian yang dilakukan oleh Rofi'ah pada tahun 2015 bahwa usia mempengaruhi proses elastis sel sel otot polos dan hal ini akan mempengaruhi proses kembalinya otot perut pasca persalinan (Rofi'ah et al., 2015).

Hasil penelitian ini selaras dengan hasil penelitian sebelumnya dari (Kasnodihardjo \& Kristiana, 2013) serta (Tumansery, 2018) bahwa perawatan tradisional yang dilakukan oleh ibu postpartum seperti massage, penggunaan ramuan, pantangan makan dan aktivitas dan melakukan kompres di perut maupun ramuan tertentu dapat mempengaruhi lingkar perut. Selain itu juga selaras dengan hasil penelitian (Puspadewi \& Chasanah, 2014) yang menyatakan bahwa olesan jeruk nipis sangat efektif dalam menghilangkan striae gravidarun dan melangsingkan perut pada ibu nifas dengan pemberian secara benar dan teratur.

Faktor faktor lain juga perlu diperhatikan dalam pengaruhnya terhadap perawatan pasca persalinan. Seperti dijelaskan oleh Rini bahwa ukuran lingkar perut pada ibu post partum di pengaruhi oleh beberapa hal salah satunya adalah komsumsi air, menggendong anak dan olah raga. Kekurangan penelitian ini adalah bahwa faktor faktor lain yang berpengaruh tersebut tidak dikendalikan, sehingga untuk peneliti berikutnya perlu memperhatikan faktor faktor lain yang berpengaruh terhadap penurunan lingkar perut beserta metodenya (Rini \& Kumala, 2017).

\section{Kesimpulan}

Penurunan lingkar perut pada responden kelompok kontrol sebelum dan sesudah dilakukan perawatan post partum sesuai protap rata-rata mengalami perubahan $2.12 \mathrm{~cm}$ dan standar deviasi meningkat menjadi 0.032 . Penurunan lingkar perut pada responden kelompok perlakuan sebelum dan sesudah dilakukan 
perawatan post partum sesuai protap rata-rata mengalami perubahan $4.44 \mathrm{~cm}$ dan standar deviasi meningkat menjadi 0.14 . Hasil penelitian menyimpulkan terdapat pengaruh pemberian borehan jeruk nipis dan kapur sirih terhadap ukuran lingkar perut ibu post partum sesuai protap puskesmas dengan nilai $t$ hitung sebesar 2,255 dan $p$ 0,032 .

\section{Ucapan Terima Kasih}

Terimakasih banyak kami ucapkan untuk pembimbing dan responden pada penelitian ini. Ucapan terimakasih juga disampaikan kepada semua pihak yang ikut berpartisipasi dalam penelitian ini.

\section{Daftar Pustaka}

Kasnodihardjo, K., \& Kristiana, L. (2013). Praktek Budaya Perawatan Kehamilan Di Desa Gadingsari Yogyakarta. Indonesian Journal of Reproductive Health, 4(3), 106736.

Khanifah, F. (2015). Efek Pemberian air perasan jeruk nipis (Cirus aurantifolia (Christm) Swingle) Terhadap Pembentukan, Pertumbuhan Dan Penghancuran Biofilm staphylococcus aureus Secara In Vitro. UIN Syarif Hidyatullah Jakarta. Jurnal Kesehatan Dan Kedokteran.

Marmi, S. (2014). Asuhan Kebidanan pada Masa Nifas 'Peuperium Care.' Yogyakarta: Pustaka Pelajar.

Mochtar, R. (2012). Sinopsis Obstetri Fisiologi dan Patologi. Jakarta EGC.
Pratiwi, A., \& Arifah, S. (2011). Perilaku Kehamilan, Persalinan Dan Nifas Terkait Dengan Budaya Kesehatan Pada Masyarakat Jawa Di Wilayah Kabupaten Sukoharjo. Jurnal Komunikasi Kesehatan (Edisi 2), 2(01).

Puspadewi, Y. A., \& Chasanah, U. (2014). Implementasi Olesan Jeruk Nipis (citrus Aurantifolia) Untuk Mengurangi Striae Gravidarum Dan Kelangsingan Perut Pada Ibu Nifas. Jurnal IImiah Kesehatan Media Husada, 3(1), 39-44.

Rini, S., \& Kumala, F. (2017). Panduan Asuhan Nifas dan Evidence Based Practice. Deepublish.

Rofi'ah, S., Yuniyanti, B., \& Isworo, A. (2015). Faktor-faktor yang berhubungan dengan Penurunan Tinggi Fundus Uteri pada lbu Nifas 6 jam Post Partum. Jurnal Riset Kesehatan, 4(2), 734-742.

Tumansery, G. S. (2018). Perawatan diri berbasis budaya selama masa nifas pada ibu postpartum. Jurnal IImu Keperawatan, 6(1), 47-56.

Yuliarti, N. (2011). 1001 Khasiat Buah-buahan. Yogyakarta: Andi. 